\title{
Motilitas spermatozoa pasca ejakulasi terkait kepentingan forensik pasca tindak kekerasan seksual
}

\author{
${ }^{1}$ Hermanus Rondonuwu \\ ${ }^{2}$ Johannis F. Mallo \\ ${ }^{2}$ Erwin G. Kristanto
}

\author{
${ }^{1}$ Kandidat Skripsi Fakultas Kedokteran Universitas Sam Ratulangi Manado \\ ${ }^{2}$ Bagian Forensik dan Medikolegal Fakultas Kedokteran Universitas Sam Ratulangi Manado \\ Email: hermanrondonuwu24@gmail.com
}

\begin{abstract}
The increasing number of sexual violence against women results in increasing number of requests from victims to prove that the sexual violence had occured. One of the examinations that is commonly used is sperm motility. This study aimed to determine the duration of spermatozoa motility post-ejaculation related to forensic importance. The results showed that there were as many as 30 samples of sperm after ejaculation. Microscopically, at the third hour it was clearly observed that half of the samples (50\%) did not show any motility at room temperature. At the fourth hour, only 13\% of samples (4 out of 30 samples) still showed spermatozoa motility. At the fifth till the eight hours all sperm samples did not show any spermatozoa motility. Conclusion: About $50 \%$ of spermatozoa could maintain their motility until 3 hours and a small part of them still showed motility until 4 hours at room temperature.
\end{abstract}

Keywords: sperm motility, post ejaculation, sexual violence, forensic analysis.

\begin{abstract}
Abstrak: Semakin maraknya jumlah kekerasan seksual yang terjadi terhadap wanita maka semakin bertambah pula jumlah permintaan dari para korban untuk melakukan pemeriksaan guna membuktikan bahwa benar telah terjadinya kekerasan seksual. Salah satu jenis pemeriksaan yang sering digunakan ialah pemeriksaan motilitas spermatozoa. Penelitian ini bertujuan untuk mengetahui lamanya motilitas spermatozoa pasca ejakulasi terkait kepentingan analisis forensik. Hasil penelitian melibatkan 30 sampel sperma pasca ejakulasi. Dari hasil pemeriksaan diperoleh bahwa pada jam ke-3 sangat jelas terlihat setengah (50\%) dari sampel yang ada sudah tidak menunjukkan kemampuan motilitas lagi dalam suhu kamar. Pada jam ke-4 jumlah sampel sperma yang masih motil hanya tersisa 13\% (4 dari 30 sampel), sedangkan pada jam ke-5 hingga jam ke-8, keseluruhan sampel sperma sudah tidak motil lagi. Simpulan: Sekitar 50\% spermatozoa mampu mempertahankan motilitas selama 3 jam, dan hanya sebagian kecil spermatozoa yang mampu mempertahankan motilitasnya maksimal selama 4 jam dalam suhu kamar.
\end{abstract}

Kata kunci: motilitas spermatozoa, pasca ejakulasi, kekerasan seksual

Kekerasan merupakan suatu persoalan global yang dapat timbul dalam berbagai bentuk baik di kehidupan publik maupun kehidupan pribadi, dan dianggap sebagai pelanggaran terhadap hak-hak asasi manusia. Salah satu bentuk dari kekerasan yang melecehkan dan menodai harkat serta martabat kemanusiaan ialah kekerasan seksual. ${ }^{1}$

Kekerasan seksual (sexual violence) merupakan salah satu praktik seks yang di nilai menyimpang, artinya praktik hubungan seksual yang dilakukan dengan cara-cara kekerasan, diluar ikatan perkawinan yang sah, dan bertentangan dengan ajaran dan norma yang berlaku. 
Kekerasan seksual itu merupakan istilah yang menunjukan pada perilaku deviatif (menyimpang), merugikan pihak korban. ${ }^{2}$ Maraknya kejadian kekerasan seksual yang terjadi pada wanita menjadi permasalahan yang patut diperhatikan. Menurut Komisi Nasional Anti Kekerasan Terhadap Perempuan (Komnas Perempuan) sejak tahun 1998 hingga 2010 hampir sepertiga kasus kekerasan terhadap perempuan adalah kasus kekerasan seksual, atau tercatat 91.311 kasus kekerasan seksual dari 295.836 total kasus kekerasan terhadap perempuan. Selama tahun 2010 tercatat 1.751 korban kekerasan seksual. $^{3}$ Berdasarkan data tersebut tidaklah mengherankan jika saat ini cukup sering terdapat permintaan pemeriksaan dari para korban maupun keluarga korban terhadap kasus-kasus yang dianggap telah mendapat kekerasan seksual. Namun satu hal yang perlu dipahamai oleh para korban dan keluarga korban bahwa di dalam pemeriksaan kasus-kasus kekerasan seksual faktor waktu dan keaslian barang bukti sangatlah penting dan merupakan penentu keberhasilan. ${ }^{4}$

Untuk dapat melakukan pembuktian adanya kekerasan seksual, tidak selamanya pembuktian kekerasan itu harus meninggalkan jejak atau bekas yang berbentuk luka. Dengan demikian tidak ditemukannya luka tidak berarti bahwa pada wanita korban tidak terjadi kekerasan. Dalam beberapa kasus juga terdapat beberapa bekas kekerasan seksual yang berupa bukti biologis. Salah satu bukti biologis yang dapat dan sering digunakan ialah cairan sperma yang terdapat di sekitar liang vagina. Sperma masih dapat bergerak atau motil dalam waktu 4-5 jam post-coital; sperma juga masih dapat ditemukan tidak bergerak sampai sekitar 24-36 jam postcoital, dan pada wanita mati masih daapt ditemukan sampai 7-8 hari. Bila persetubuhan telah dapat dibuktikan secara pasti, maka memperkirakan saat terjadinya kekerasan seksual yang mendekati ketepatan mempunyai arti penting, khususnya bila dikaitkan dengan proses penyidikan. Oleh karena itu penyidik dapat lebih terarah dan selektif di dalam melakukan pemeriksaan terhadap para tersangka pelaku tindak pidana. Hal ini menyangkut benar tidaknya alibi seseorang yang diduga mempunyai hubungan dengan sebab terjadinya tindak kekerasan seksual tersebut, dapat diperkirakan melalui saat kematian. $^{4}$

\section{METODE PENELITIAN}

Jenis penelitian ini perspektif deskriptif dengan menggunakan metode kohort. Penelitian ini dilakukan pada periode Oktober 2014 sampai Desember 2014 di Bagian Forensik Fakultas Kedokteran Universitas Sam Ratulangi Manado. Kriteria inklusi ialah laki-laki dengan umur 17-25 tahun. Populasi yang digunakan sebanyak 30 orang dengan kriteria eksklusi ialah laki-laki yang menderita oligosperma dan azosperma. Variabel penelitian ini ialah tingkat motilitas spermatozoa dari masing-masing subjek. Alat dan bahan yang digunakan dalam penelitian ini yaitu kaca objek, mikroskop cahaya, jam (pengukur waktu), akuades, rak preparat, kaca penutup, pipet, wadah penampung sperma, sperma (yang disimpan dalam suhu ruangan) dan Nacl $0.9 \%$.

Prosedur penelitian yaitu, sebanyak 30 orang laki-laki umur 17-25 tahun diberikan informed concern untuk bersedia mendonorkan spermanya untuk diteliti. Sperma langsung diperiksa sesaat setelah diejakulasikan. Setiap harinya dalam kurun waktu yang ditentukan, diambil 1-3 sampel sperma yang akan diperiksa motilitasnya selama 8 jam. Pemeriksaan motilitas sperma dilakukan dengan menggunakan kaca obyek dan mikroskop cahaya dengan pembesaran objektif 40x dan tiap sampel diperiksa sebanyak 8x dalam kurun waktu 8 jam. Hasil pemeriksaan yang didapat, segera dicatat untuk digunakan dalam proses selanjutnya.

\section{HASIL PENELITIAN}

Tabel 1 memperlihatkan bahwa pada jam ke-1 kemampuan motilitas dari semua sampel sperma masih terlihat. Pada jam ke- 
2 sebagian besar sperma masih menunjukan motilitas yang baik dan hanya 20\% atau 6 dari 30 sampel yang sudah tidak motil lagi. Pada jam ke-3 sangat jelas terlihat bahwa setengah dari jumlah sampel yang ada (50\%) sudah tidak menunjukkan motilitasnya lagi. Hal ini menunjukkan bahwa rata-rata sampel sperma telah kehilangan motilitasnya pada jam ke-tiga. Pada jam ke-4 jumlah sampel sperma yang masih motil hanya tersisa $13 \%$ atau hanya 4 dari 30 sampel. Hal ini menunjukkan bahwa 4 dari 30 sampel merupakan sampel sperma yang mampu bergerak (masih motil) hingga 4 jam, dan ini merupakan waktu yang terlama dari semua sampel yang ada. Pada jam ke-5 hingga jam ke-8, keseluruhan sampel sperma sudah tidak motil lagi.

Tabel 1.Motilitas sperma setiap 1 jam

\begin{tabular}{lcccccccc}
\hline & Jam 1 & Jam 2 & Jam 3 & Jam 4 & Jam 5 & Jam 6 & Jam 7 & Jam 8 \\
\hline $\begin{array}{l}\text { Jumlah } \\
\begin{array}{l}\text { Sperma } \\
\text { yang masih } \\
\text { motil } \\
\text { (sample) }\end{array}\end{array}$ & 30 & 24 & 15 & 4 & 0 & 0 & 0 & 0 \\
\hline
\end{tabular}

\section{BAHASAN}

Hasil analisis menunjukkan bahwa pemeriksaa selama 8 jam pada semen yang berbeda memberikan pengaruh perbedaan yang sangat nyata terhadap motilitas spermatozoa dalam pengencer $\mathrm{NaCl}$ yang disimpan pada suhu kamar dengan waktu yang masih memberikan kelayakan kualitas spermatozoa yaitu selama 4 jam. ${ }^{5}$ Terdapat dua faktor yang memengaruhi motilitas spermatozoa, yaitu faktor eksogen dan faktor endogen. Faktor eksogen adalah faktor yang berasal dari lingkungan di luar membran spermatozoa, antara lain faktor biofisika dan faal meliputi viskositas, $\mathrm{pH}$, temperatur, dan komposisi ion dalam media yang ada disekelilingnya. Faktor endogen merupakan keadaan individu spermatozoa yang berkaitan antara lain dengan umur spermatozoa, tingkat maturasi spermatozoa, sifat biokimia dan juga faktor yang memengaruhi tersedianya energi. ${ }^{6}$ Motilitas atau daya gerak spermatozoa yang dinilai segera sesudah penampungan semen, digunakan sebagai ukuran kesanggupan membuahi suatu contoh semen. Sewaktu penampungan harus diperhatikan agar ejakulasi tidak mengalami "Cold shock" atau penurunan suhu secara mendadak yang sangat memengaruhi motilitas sperma. ${ }^{7}$ Panas ruang berlebihan dan zat kimia lainnya juga dapat menurunkan motilitas sperma. Daya hidup spermatozoa di luar tubuh sangat rendah dan mudah sekali mengalami kematian. Pada suhu rendah penurunan metabolisme spermatozoa mudah terjadi. Motilitas spermatozoa dalam suatu contoh semen ditentukan secara keseluruhan atau sebagai rata-rata dari suatu populasi sperma. ${ }^{8}$ Penurunan motilitas individu dan viabilitas spermatozoa terjadi karena pengencer $\mathrm{NaCl}$ fisiologis termasuk garam sederhana dengan kemampuan terbatas dan juga sifat kimiawi spermatozoa dengan metabolisme sel yang dapat menjadi racun bagi kehidupannya. ${ }^{9}$ Yulnawati dan Setiadi (2005) menjelaskan bahwa spermatozoa yang mati akan menjadi toksik terhadap spermatozoa lain yang masih hidup, sehingga secara umum kualitasnya menurun. Keberadaan zat yang bersifat toksik baik berasal dari spermatozoa yang telah mati maupun yang berasal dari zat yang terkandung dari pengencer yang telah mengalami oksidasi akibat penyimpanan dapat menyebabkan tingginya kadar radikal bebas yang dapat merusak keutuhan 
membran plasma spermatozoa. ${ }^{10}$ Mekanisme bercampurnya larutan $\mathrm{NaCl}$ dengan plasma semen serta spermatozoa yang seimbang mampu menciptakan suasana yang isotonis dan dapat mempertahankan daya hidup spermato-zoa. Osmosis hanya terjadi jika terjadi perbedaan konsentrasi zat terlarut yang tidak dapat menembus membran plasma di intrasel dan ekstrasel. Ion natrium merupakan zat terlarut yang banyak ditemukan pada cairan ekstrasel, dan berperan penting dalam menentukan aktivitas osmotik cairan ekstrasel. Penurunan motilitas diduga berkaitan dengan ion $\mathrm{Ca}^{++}$yang dapat memengaruhi membran plasma dari spermatozoa itu sendiri. ${ }^{11}$ Namun di balik semua faktor tersebut terdapat faktor utama yang mampu menghilangkan motilitas spermatozoa, yaitu faktor asupan energi untuk bergerak. Semakin lama semen berada di suhu ruangan maka akan semakin meningkatkan tingkat kematian spermatozoa karena rusaknya membran plasma yang berakibat pada terganggunya suplai energi spermatozoa sehingga menurunkan motilitas. Jumlah spermatozoa yang mati akan memengaruhi spermatozoa yang masih hidup selama proses penyimpanan. ${ }^{12}$ Menurut Hammerstedt (1993) selain meningkatkan produksi asam laktat pada saat penyimpanan, radikal bebas merupakan hasil proses transpor elektron dari mitokondria yang dapat menyebabkan peroksidasi lemak sehingga mematikan spermatozoa. Radikal bebas memiliki daya rusak yang tinggi terhadap asam lemak tidak jenuh yang merupakan komponen utama dalam pembentukan fosfolipid membran plasma spermatozoa, ${ }^{13}$ Jika membran plasma rusak maka akan berlanjut pada internal sel sehingga dapat menurunkan daya hidup dan motilitas. Membran plasma yang rusak akan menyebabkan terganggunya metabolisme sehingga produksi ATP sebagai sumber energi berkurang. ${ }^{14}$ Oleh karena itu, dapat disimpulkan bahwa faktor-faktor yang memengaruhi motilitas sperma ialah cadangan energi (ATP), umur sperma, maturasi sperma, agen aktif, biofisik, fisiologik, cairan suspensi, serta rangsangan hambatan. ${ }^{15}$ Bukti cairan seminal digunakan untuk dua tujuan utama, yaitu untuk mengidentifikasi pelaku dan untuk mengonfirmasi mengenai terjadinya kontak seksual. Bukti ini juga diperkirakan sebagai bukti penguat. Akan tetapi persentase dari pemerkosaan yang memiliki disfungsi seksual dan yang lain menggunakan kondom atau ejakulasi diluar menjadi faktor penting yang patut untuk diingat bahwa bila tidak terdapat cairan semen maka pelaku dapat menyangkal adanya kontak seksual. Bukti cairan semen dianalisis oleh personel laboratorium untuk menentukan adanya spermatozoa sebagai barang bukti yang dapat membuktikan terjadinya kontak seksual dan dapat menentukan waktu terjadinya kontak tersebut.

\section{SIMPULAN}

Dari hasil penelitian ini dapat disimpulkan bahwa rata-rata motilitas spermatozoa hanya mampu bertahan selama 3 jam dan sebagian kecil spermatozoa lainnya hanya mampu bertahan maksimal 4 jam dalam suhu kamar.

\section{SARAN}

Penelitian ini dapat dikembangkan dengan jumlah sampel yang lebih banyak dan juga dilakukan pemeriksaan mengenai faktor-faktor yang dapat memengaruhi spermatozoa.

\section{DAFTAR PUSTAKA}

1. Ratna SS. Etika Kedokteran Indonesia. Jakarta: Yayasan Bina Pustaka Sarwono Prawirohardjo, 2001; p. 202.

2. Abdul W, Muhammad I. Perlindungan terhadap korban kekerasan seksual. Bandung: PT Refika Aditama, 2011.

3. Abdussalam HR. Forensik (3rd ed). Jakarta: Restu Agung, 2006; p. 139-49.

4. Idries AM. Penerapan Ilmu Kedokteran Kehakiman dalam Proses Penyidikan. Jakarta: Karya Unipress, 1998.

5. Sudoyo AW, Setiyohadi B, Idrus A, Simbdibrata M, Setiati S, editors. 
Buku ajar Penyakit Dalam (5th ed). Jakarta: Bagian Ilmu Penyakit Dalam FK UI, 2009.

6. Adimmunca C, Sutyarso. Inhibin sebagai bahan alternatif kontrasepsi pria. Pusat Penelitian Penyakit Tidak Menular. Jakarta: Badan Penelitian dan Pengembangan Kesehatan Departemen Kesehatan RI, 1997; p. 34.

7. Ganong W. Buku Ajar Fisiologi Kedokteran (20th ed). Jakarta: EGC,, 2002; p. 509-11.

8. Sherwood L. Fisiologi Manusia (2nd ed). Jakarta: EGC, 2001; p. 697-700.

9. Sikka SC. Role of oxidative stress and antioxidants in andrology and assisted reproductive technology. Journal of Andrology. 2004;25(1): 6-8.

10. Winarsi H. Antioksidan alami dan radikal bebas: potensi dan aplikasinya dalam kesehatan. Yogyakarta: Kanisius,, 2007; p. 37.

11. World Health Organization (WHO). Penuntun laboratorium WHO untuk pemeriksaan semen manusia dan interaksi semen-getah serviks. Tadjudin MK, penerjemah. Jakarta: FK-UI, 1988; p. 14.

12. Yatim W. Reproduksi dan embriologi. Bandung: Tarsito, 1994; p. 32.

13. Marks DB, Marks AD, Smith CM. Biokimia Kedokteran Dasar. Jakarta: EGC, 2009; p. 20.

14. Husada. Artikel kesehatan RS 2011. 2011. [cited 2014 dec 9]. Available from: www.ANALISIS-SPERMA-danKESUBURAN-PRIA.htm.

15. Fauzi A. Permeriksaan spermatozoa 2010. 2010. [cited 2014 Dec 9]. Available from: www.mahasiswa-berbagimotilitas-sperma.htm. 